\title{
DETERMINATION OF SOME HAEMATOLOGICAL PARAMETERS IN MALARIA INFECTED SUBJECTS IN USMANU DANFODIYO UNIVERSITY TEACHING HOSPITAL (UDUTH) SOKOTO, NIGERIA
}

\author{
*Garba, $\mathbf{N}^{\mathbf{1}}$., Danladi, S. ${ }^{1}$., and Muhammad, A $^{\mathbf{2}}$. \\ ${ }^{1}$ Department of Medical Laboratory Science, Bayero University, P.M.B. 3011, Kano, Nigeria. \\ ${ }^{2}$ Department of Medical Laboratory Science, School of Health Technology, Jahun, Jigawa, Nigeria. \\ *Correspondence author: garbanura001@gmail.com, *+2348033364865
}

\begin{abstract}
Since malaria parasites are able to attach to receptors on the red blood cell surface, it is expected that malaria parasites may have effect on some haematological parameters. Haematological parameters are often needed to assist in the management of malaria infection. The aim of this study is to assess the effects of malaria parasites on some haematological parameters in Sokoto Nigeria. To investigate the effects of malaria infection on red blood cells, white blood cells and platelets, 100 malaria positive adults (15-60 years) attending Usmanu Danfodiyo University Teaching Hospital, Sokoto, Nigeria were enrolled into the study for a period of seven months; April through October 2009. Malaria parasitaemia was determined microscopically by stained thick film, packed cell volume (PCV) by microhaematocrit method, while total white blood cell count (TWBC) and platelet count (PLC) by manual methods. The total of 100 malaria infected patients and 50 apparently healthy malaria non-infected students were compared against PCV, TWBC and PLC values using student's t-test. The results of PCV and PLC showed statistically significant decrease among malaria infected patients $(p<0.05)$ while for TWBC there was statistically significant increase $(p<0.05)$ among $18 \%$ of malaria infected subjects. When PCV, TWBC and PLC values of males and females infected with malaria parasite were compared, the PCV value showed statistically significant decrease in females $(p<0.05)$, while TWBC and PLC values showed no statistically significant difference between males and females $(p>0.05)$. These findings indicate that malaria infection has an impact on some haematological parameters, therefore, malaria infection in this community contributes to the severity of anaemia and thrombocytopenia.

Key words: Malaria infection, packed cell volume (PCV), total white blood cell count (TWBC),
\end{abstract} platelet count (PLC), anaemia.

\section{INTRODUCTION}

Malaria is a major public health problem and cause of suffering and premature death in tropical and subtropical countries (Cheesbrough, 1998). In many endemic areas it is becoming increasingly difficult to control because of the resistance of the parasite to antimalarial drugs and the failure of vector control measures (Cheesbrough, 1998).

Malarial parasites belong to the genus Plasmodium. Plasmodium is the only genus belonging to the family Plasmodiidae, order Haemosporida, class Coccidea, phylum Sporozoa(Apicomplexa). The genus contains over 125 species that cause malaria in mammals, reptiles and birds (Hommel and Gilles,2006). There are four species, which include; $P$. falciparum, $P$. vivax (wide spread), $P$. ovale and $P$. malariae (less widely spread) (Hommel and Gilles, 2006).

In Nigeria, there are over 100 million people at risk of malaria every year and it is estimated that about $50 \%$ of the adult population experience at least one episode yearly (Igbeneghu and Odaibo, 2013).Malaria causes a lot of debilitating effect in adults and the yearly economic loss due to malaria in Nigeria has been put at 132 billion Naira comprising cost of treatment and transport to source of treatment, loss of man-hours, absenteeism from places of work and other indirect cost (Igbeneghu and Odaibo, 2013).

Hematological alterations that are thought to characterize malaria may be related to the overt biochemical changes that occur during the asexual stage of the life cycle of the malaria parasite. Entry of $P$. falciparuminto erythrocytes usually leads to a marked increase in secretion of inflammatory cytokines (TNFa, IL-1, IL-10, and IFN $\gamma$ ), endothelial cell activation (due to overexpression of cell adhesion molecules; ICAM-1, VCAM-1), activation of the coagulation cascade (due to platelet consumption and endothelial damage), and sequestration of parasitized RBCs (Haruna et al., 2013). Certain haematological changes which include low platelet count, haemoglobin concentration and hematocrit have been reported to be associated with malaria (Kumar and Shashirekha, 2006). This study was aimed to assess the effects of malaria parasites on some haematological parameters in Sokoto Nigeria, with the objective to determine the PCV, TWBC and PLC among malaria infected patients and apparently healthy non malaria infected students. 


\section{MATERIALS AND METHODS \\ Study Area}

The area selected for this research work was Usmanu Danfodiyo University Teaching Hospital (UDUTH) located in Sokoto metropolis, Sokoto state of Nigeria. The metropolitan city of Sokoto lies between longitude $05^{0} 11^{1}$ to $13^{0} 03^{1}$ East and latitude $13^{0} 00^{1}$ to $13^{0} 06^{1}$ North and covers an area of $60.33 \mathrm{~km}^{2}$ (Iman, 2006). The area has an annual mean rainfall ranging between $500 \mathrm{~mm}$ to $1,300 \mathrm{~mm}$. Dry season starts from October and lasts up to May and wet season begins in May and lasts up to October every year (Iman, 2006). The total population of people in Sokoto metropolis for 2006 is 505,004, based on the 2006 census. The indigenous inhabitants of the study area are mainly Hausa and Fulani. Other ethnic groups resident in the area include Igbo, Yoruba, Nupe, Ebira, Igala, etc. Hausa is the commonly spoken language. Traders form greater percentage of the population, while the rest are civil servants, farmers, artisans and people of other occupation (Iman, 2006).

\section{Study Subjects}

The sample size was calculated using single proportion formula, however, 150 samples were studied in which 100 were malaria infected patients and 50 were apparently healthy malaria non infected students (aged between 15-60 years) attending Usmanu Danfodiyo University Teaching Hospital.

\section{Inclusion Criteria}

Only malaria positive patients attending UDUTH and apparently healthy students who were malaria negative were considered eligible for enrollment into the study.

\section{Exclusion Criteria}

All subjects with any of the following were excluded: typhoid fever, pregnant women, other obvious medical conditions and apparently healthy students who were positive for malaria parasite (for control).

\section{Sample Collection}

A $2.5 \mathrm{ml}$ of blood was collected under aseptic condition by venopuncture into $0.04 \mathrm{ml}$ of EDTA bottle from malaria positive patients attending UDUTH and malaria negative students (control) living in students' hostel. The sample collected was gently inverted 5-6 times to prevent clotting. Participants' demographic data were documented. In not more than one hour of sample collection, each sample collected was then tested for the following haematological parameters:
1. Packed cell volume (PCV)
2. Total white blood cell count (TWBC)
3. Platelet count (PLC)

\section{Techniques}

Identification of malaria parasite was done microscopically by stained thick film. PCV, TWBC and PLC were estimated using Dacie and Lewis (1995) methods.

\section{Data Analysis}

\section{Instrument:}

Data processing was done using the Graph pad Instat computer statistical software package (Version 5.00), developed in 2007.

\section{Presentation and Test Statistics:}

Mean \pm Standard Deviation of PCV, TWBC and PLC in malaria infected and non-infected adults were found. The t-test was used to compare differences between variables and $p<0.05$ was considered as statistically significant.

\section{RESULTS}

The mean age \pm SD of adults was $33.35 \pm 13.05$ years. Out of 100 malaria infected patients, 64 were males and 36 were females. Among the 50 malaria negative students, 31 were males while the remaining 19 were females.

Table 1 Compares Mean \pm Standard Deviation of the PCV, TWBC and PLC in malaria infected and noninfected adults. The Mean \pm Standard Deviation of PCV in infected was $38.38 \pm 4.46 \%$ while in noninfected was $41.42 \pm 4.38 \%$. The Mean \pm Standard Deviation of TWBC in infected was $8.32 \pm 2.99 \times 10^{9} / \mathrm{L}$ while in non-infected was $6.67 \pm 1.55 \times 10^{9} / \mathrm{L}$. The Mean \pm Standard Deviation of PLC in infected was $194.56 \pm 60.70 \times 10^{9} / \mathrm{L}$ while in non-infected was $264.06 \pm 76.68 \times 10^{9} / \mathrm{L}$. Statistical analysis among the two variables for PCV shows $p$-value $=0.0014$ indicating a very significant decrease among malaria infected patients. Statistical analysis for TWBC indicates extremely significant increase among malaria infected patients ( $p$-value $=0.0008)$. The PLC shows extremely significant decrease in malaria infected patients ( $p$-value $=0.0001$ ).

Table 2 Compares Mean \pm Standard Deviation of the PCV, TWBC and PLC in malaria infected males and infected females adults. The Mean \pm Standard Deviation of PCV in infected males was $39.58 \pm 4.49 \%$ while in infected females was $36.25 \pm 3.58 \%$. The Mean \pm Standard Deviation of TWBC in infected males was $8.35 \pm 3.06 \times 10^{9} / \mathrm{L}$ while in infected females was $8.28 \pm 2.90 \times 10^{9} / \mathrm{L}$. The Mean \pm Standard Deviation of PLC in infected males was $198.06 \pm 61.97 \times 10^{9} / \mathrm{L}$ while in infected females was $191.11 \pm 60.49 \times 10^{9} / \mathrm{L}$. Statistical analysis among the two variables for PCV shows $p$-value $=0.0016$ indicating very significant decrease in females. Statistical analysis for TWBC and PLC indicate no significant difference among the sexes ( $p$-value = 0.8720 and $p$-value $=0.8754$ respectively).

Table 1: Compares Mean \pm Standard Deviation of the PCV, TWBC and PLC in Malaria Infected and Non-infected Adults.

\begin{tabular}{|c|c|c|c|}
\hline Parameters & $P C V(\%)$ & $T W B C\left(X 10^{9} / L\right)$ & $\operatorname{PLC}\left(X 10^{9} / L\right)$ \\
\hline Malaria infected $(\mathrm{N}=100)$ & $38.38 \pm 4.46$ & $8.32 \pm 2.99$ & $194.56 \pm 60.70$ \\
\hline $\begin{array}{l}\text { Malaria Non-infected }(\mathrm{N}=50) \\
\mathrm{t} \text {-value }\end{array}$ & $\begin{array}{c}41.42 \pm 4.38 \\
3.16\end{array}$ & $\begin{array}{c}6.67 \pm 1.55 \\
3.56\end{array}$ & $\begin{array}{l}264.06 \pm 76.68 \\
4.83\end{array}$ \\
\hline$p$-value & 0.0014 & 0.0008 & $<0.0001$ \\
\hline
\end{tabular}

Key: Results are presented as Mean \pm Standard Deviations (SD), $\mathrm{N}=$ Number of subjects, PCV = Packed cell volume, TWBC $=$ Total white blood cell count, $\mathrm{PLC}=$ Platelet count 
Table 2: Compares Mean \pm Standard Deviation of the PCV, TWBC and PLC in Malaria Infected Males and Infected Females Adults.

\begin{tabular}{l|lll}
\hline Parameters & $\boldsymbol{P C V}(\boldsymbol{\%})$ & $\boldsymbol{T W B C}\left(\boldsymbol{X 1 0 ^ { 9 }} / \mathbf{L}\right)$ & PLC $\left(\boldsymbol{X 1 0 ^ { 9 }} / \mathbf{L}\right)$ \\
\hline $\begin{array}{l}\text { Infected Males } \\
\text { (N=64) }\end{array}$ & $39.58 \pm 4.49$ & $8.35 \pm 3.06$ & $198.06 \pm 61.97$ \\
$\begin{array}{l}\text { Infected Females } \\
\text { (N=36) }\end{array}$ & $36.25 \pm 3.58$ & $8.28 \pm 2.90$ & $191.11 \pm 60.49$ \\
t-value & 3.411 & 0.1623 & 0.1579 \\
\hline p-value & 0.0016 & 0.8720 & 0.8754 \\
\hline
\end{tabular}

Key: Results are presented as Mean \pm Standard Deviations (SD), PCV = Packed cell volume, TWBC = Total white blood cell count, PLC = Platelet count

\section{DISCUSSION}

Haematological parameters such as PCV, TWBC and PLC are very important in the management of malaria infected patients. The results obtained from this study show that the PCV value is slightly lower in malaria infected subjects (about $38 \%$ ). This finding is slightly different from the work done by Samje et al., 2009 in the University of Buea Cameroon where they had $45 \%$ decrease in PCV level among malaria infected patients.

This decrease in PCV level (anaemia) may be due to some degree of haemolysis in malaria infected patients (Hoffbrand et al., 2005). It may also be due to Normocytic, Normochromic anaemia (anaemia of chronic disease) seen in malaria infected subjects (Hoffbrand et al., 2006).

This research work shows that platelet count is slightly reduced in malaria infected patients. We found about $70 \times 10^{9} / \mathrm{L}$ difference in platelet count among malaria infected patients and malaria non infected students (table 1 ). This is also similar to the report of Cheesbrough (2000) and Hoffbrand et al., (2005) that mild thrombocytopenia with counts down to $100 \times 10^{9 /}$ Lis common in malaria infected patients. Thrombocytopenia in malaria infection was also reported in Uttarakhand State of India (Smita and Harish, 2013). This decrease in platelet count (thrombocytopenia) might be due to mild splenomegaly reported in some malaria infected patients (Hoffbrand et al., 2005).

\section{REFERENCES}

Cheesbrough, M. (1998). District Laboratory Practice in Tropical Countries. Cambridge, UK: Cambridge University Press; Part (1). P. 239, 243.

Cheesbrough, M. (2000). District Laboratory Practice in Tropical Countries. Cambridge, UK: Cambridge University Press; Part (2). P. 314-8.

Dacie, J.V. and Lewis, S.M. (1995). Practical Haematology. $8^{\text {th }}$ ed. London, UK: Churchill Livingstone; P. 433-4.

Haruna, M. Sharif, K. Larry, F.S. Abdul, S. and Christine N. (2013). How Reliable Are Hematological Parameters in Predicting Uncomplicated Plasmodium falciparum Malaria in an Endemic Region?Hindawi Publishing Corporation, ISRN Tropical Medicine, Volume 2013, Article ID
The results obtained from this research show that white cell count is slightly increased in malaria infected patients. The TWBC mean value of malaria infected patients was about $2 \times 10^{9} / \mathrm{L}$ greater than that of non malaria infected students and this difference was statistically significant ( $p$-value $=0.0008)$. Rise in white cell count was also reported in severe malaria (Hoffbrand et al., 2005). This increase may also be due to neutrophilia reported in most cases of acute haemorrhage or due to monocytosis as seen in most cases of malaria infection (Cheesbrough, 2000). This finding is different from the work done in aSemi-Urban Community in Southwestern Nigeria where they found leucopenia in acute malaria infection (Igbeneghu and Odaibo, 2013). Finally, this research work also shows that the lower the PCV, the higher the white cell count and vice versa, this may be due the fact that increase in one cell lineage production may cause decrease in other cell lineage production.

\section{CONCLUSION}

This study found that malaria has significant impact on some haematological parameters in which low PCV, low PLC and high TWBC occur.

\section{Acknowledgements}

The authors want to acknowledge the assistance of the Usmanu Danfodiyo University Teaching Hospital, Sokoto. Our gratitude also goes to the participants of this research.

$673798, \quad 9$
http://dx.doi.org/10.1155/2013/673798

Hoffbrand, A. Victor, D. and Edward, G.D. T. (2005). Postgraduate Haematology. $5^{\text {th }}$ ed. Massachusetts, USA: Blackwell publishing Ltd; P. 976, 981-2, 985.

Hoffbrand, A.V. Pettit, J.E. and Moss, P.A.H. (2006). Essential Haematology. $5^{\text {th }}$ ed. Massachusetts, USA: Blackwell publishing Ltd; P. 330-1.

Hommel, M. and Gilles, H.M. (2006). Topley and Wilson's microbiology and microbial infections. Malaria. $4^{\text {th }}$ ed. Edward Amold (Publishers) Ltd.

Igbeneghu, C. and Odaibo,A.B.(2013).Impact of Acute Malaria on Some Haematological Parameters in A Semi-Urban Community in Southwestern Nigeria.Acta Parasitologica Globalis 4 (1). 
Bajopas Volume 8 Number 1June, 2015

Iman, A. (2006). Prevalence of coliform bacteria on environmental surface in day care centres and Nursery Schools in Sokoto metropolis MPH Dissertation, Usmanu Danfodiyo University Sokoto.

Kumar, A. and Shashirekha. (2006). Thrombocytopenia- an indicator of acute vivax malaria. Indian J Pathol Microbiol; 49: 505-508. PMid: 17183838
Samje, M. Sumbele, I. Njunda, A. Mankah, E. Kamga, L. and Akenji, T.N. (2009). Assessment of Packed Cell Volume (PCV) and Plasma Iron Levels Following Treatment for Malaria and Helminthic Infections in Children in Rural Muea, Cameroom. African Education Initiative International Scientific Conference, www.nef3.org. pp;66

Smita, C and Harish, C. (2013). Role of hematological parameters as an indicator of acute malaria infection in Uttarakhand State of India. Mediterranean Journal of hematology and infectious diseases. Vol 5 , No 1 